\title{
亜共析普通炭素鋼の加熱冷却繰返しによる 顐微鏡組織の変化についで
}

三 浦 寛 ${ }^{* *}$

Hiroshi Miura : On the Changes in the Microstructure of Hypo-eutectoid Carbon Steel by Thermal Cycling. The changes in the microstructure of a hypo-eutectoid carbon steel by thermal cycling below $A c_{1}$ was investigated by the point counting method. The maximum heating temperature of thermal cycling was $690^{\circ} \mathrm{C}$ and the holding time was 240 seconds. In order to find out the characteristic feature of the changes in the microstructure by thermal cycling, the changes in the microstructure by steady (isothermal) heating were compared with those by thermal cycling.

The lamellar pearlite of the original structure was spherodized and the hardness was decreased by thermal cycling. The finer lamellar pearlite, the quicker this spherodizing process was proceeded. The rate of the spherodization by thermal cycling was more than twice as fast as in the case of steady heating. The characteristic features of spherodization by thermal cycling are as follows. The spherodized pearlite cementite was fine and uniform. The shape of pearlite colony was not changed so much by the spherodization. And the spherodizing process was proceeded very quickly in the colony. It was considered that the rapid spherodization by thermal cycling was due to the decomposition of the pearlite cementite at many positions and the precipitation of the fine spherical cementite in the proeutectoid ferrite by thermal cycling.

(Received January 10, 1969)

\section{I. 緒}

鉄鋼材料の熱疲労に関するこれまでの研究の多くは, 割 れ発生までの寿命の推定 ${ }^{(1)(2)}$ に関するものであり，熱瘦労

** 室蘭工業大学金属工学科 (Department of Metallurgy, Muroran Institute of Technology, Muroran)

* 1965 年 4 月本会東京大会に発表

(1) L.F.Coffin: Trans.ASME, 76 (1954), 931.

(2) 日本材料学会, 疲学部門委員会研究報告 : 材料, 13 (1963), No.131, 554 .
に関する金属組織学的な知見は非常に少ない，著者は加熱 冷却の繰返し(以下繰返加熱之略ず)により材料の金属組織 学的性質が変化することが熱疲労の破壊現象の本質的な原 因であるうと考㐫るあのである、このため，著者は繰返加

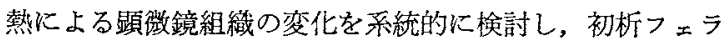
イトに括ける变化について報告(3)〜(5) した。

(3) 三浦, 大内：本誌，30(1966)，361.

(4) 三浦 : 本誌, 31 (1967), 964.

(5) 三浦 : 本誌, 31 (1967), 970. 
この報告はおもにパーライト組織の変化に関するもので ある. 繰返加熱执よび定常的加熱 (恒温連続的加熱)による パーライトの変化を定量的に調べることにより，繰返加熱 によるパーライトの変化の特色を明らかにすることを目的 として行なつた実験結果について述べる. そして, 繰返加 熱によるパーライトの変化と初析フェライトの変化との関 係を明らかにしたい。

パーライトが共析変態点以下の温度で加熱されることに より粒状化することは経験的に知られているが, 繰返加熱 によるパーライトの変化を検討した報告はほとんど見当ら ない.川崎ら ${ }^{(6)(7)}$ は丸棒型試験片を真空カプセルに封入し て,「電気炉加熱一水冷方式」の繰返加熱を行なつた場合の 低炭素鋼のパーライトの変化について報告している. 定常 的加熱によるパーライトの変化に関する研究は数多いが, 大部分はかなり古い研究であり, 定常的加熱によつてはパ 一ライトが粒状化しないと主張する説 ${ }^{(8)}$ (10), 粒状化する と主張する説 ${ }^{(11)(12)}$ 加熱過程に温度変化があれば粒状化す ると主張する説(13) などがありまちまちである。最近では パーライトの粒状化を取扱つた論文は非常に少ない。

\section{II. 実 験 方 法}

供試材は市販の機械構造用炭素鋼, S $35 \mathrm{C}(0.39 \% \mathrm{C}$, $0.68 \% \mathrm{Mn})$ 扣よび電解鉄を素材として大気中溶製 $(5 \mathrm{~kg})$ 後，鍛造した $\mathrm{Fe}-0.32 \% \mathrm{C}$ 鋼 $(0.32 \% \mathrm{C}, 0.13 \% \mathrm{Si}, 0.01 \%$ $\mathrm{Mn})$ である. 供試材, S $35 \mathrm{C}$ は焼準 $\left(850^{\circ} \mathrm{C}\right.$, 空冷) 後, 焼鈍 $\left(820^{\circ} \mathrm{C}\right.$, 炉冷, 砂冷および空冷)により原組織(熱処理まま の組織)のパーライトを粗い層状パーライト，層状パーラ イト持よひ微細パーライトに調整した， Fe-0.32\% C 鋼は 粗い層状パーライト $\left(830^{\circ} \mathrm{C}\right.$, 炉冷) とした。焼鈍後，小円 柱型の試験片 $(10 \phi \times 10 \mathrm{~mm})$ に切削し，小孔をあけたステ ンレス製の小箱に入れ，9 個まとめて繰返加熱を行なつた. 試験片を $690^{\circ} \pm 5^{\circ} \mathrm{C}$ に保持中の塩浴中に 5 分間浸漬して加 熱し, 室温の流水中に急冷する方式にて繰返加熱を行なつ た，試験片の浸漬による塩浴の温度低下を防ぐため，塩浴 の容量は著しく大きく $(80 \phi \times 500 \mathrm{~mm})$ した。塩浴は市販 の塩化物系中性塩浴剤であり, 融点は約 $400^{\circ} \mathrm{C}$ である. 繰 返加熱の熱サイクルの加熱過程と冷却過程の時間 - 温度曲 線はFig.1 に示したと特りである．Fig.1 は小円柱型試験 片に熱電対を溶接し，熱電対の周囲を鋼管で保護して測定

（6）川崎, 笹川, 相沢 : 材料試験, 10(1961), 215.

（7）川崎, 笹川, 相沢, 薄井 : 材料試験, 11 (1962), 176.

(8) J.H. Whitley : J.Iron Steel Inst., $97(1918), 353$.

(9) Honda and Saito: J.Iron Steel Inst., 102(1920), 261.

(10) A.Portrin and V. Bernard : J. Iron Steel Inst., 105 (1921), 145.

(11) C.H.Desh and A.T.Roberts : J.Iron Steel Inst., 107 (1923) , 243.

(12) H. Hanemann and F. Morawe : Stahl u. Eisen, 33 (1913), 1350.

(13) 佐藤, 矢嶋：鉄と鋼, $37(1951), 92$.
した結果である. 試験片の真の温度変化は Fig.1 より急激

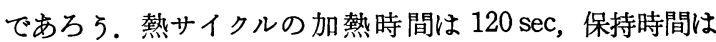
$180 \mathrm{sec}$ である。加熱速度は熱サイクル初期で約 $50^{\circ} \mathrm{C} / \mathrm{sec}$, $690^{\circ} \sim 200^{\circ} \mathrm{C}$ 間の平均冷却速度は約 $50^{\circ} \mathrm{C} / \mathrm{sec}$ と測定され た. 繰返加熱操作は非常に危険ではあるが手で最高 400 サ イクルまで行なつた. 所要の繰返加熱後, 試験片の深さ約 $2 \mathrm{~mm}$ の横断面中心部の顕微鏡 組織とビッカース硬度を調 ベた. 繰返加熱後の組織は後述するポイントカウンティン グ法によつて組織解析を行なつた。

な拉, 繰返加熱の場合と同じ加熱速度, 保持温度および 冷却速度によつて定常的加熱を行ない, 試験片の組織と硬 度を調べた。

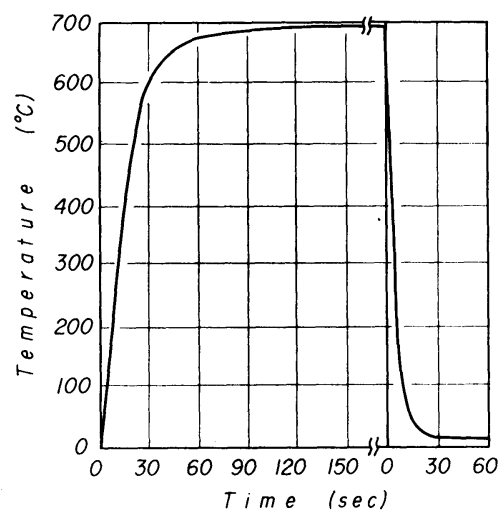

Fig.1 Time-temperature curves of heating and cooling process of the thermal cycle. Specimen : $10 \phi \times 10 \mathrm{~mm}$. Heating : salt bath, $690^{\circ} \mathrm{C} \times 5 \mathrm{~min}$, Cooling : water

\section{III. 実 験 結 果お よび考察}

\section{1. 加熱冷却繰返しによる亜共析} 炭素鋼の顥微鏡組绕の变化

Photo.1 は原組織 (HT) が粗い層状パーライトと初析フ ェライトよりなる場合（粗い層状パーライトの場合と略す る) の繰返加熱による組織の変化である。この写真で明ら かなように，繰返数の増加とともに原組織の層状パーライ トはその層状性を失い粒状化が進行している。初析フェラ イトには微粒セメンタイト ${ }^{(3)}$ が認められる. 繰返加熱によ るパーライトの粒状化の特色は粒状化によりパーライトコ ロニーの形が著しく変化しないことである，組織を詳細に 観察すると，つぎのと括りである，パーライトの粒状化の 優先する位置はフェライト粒界に接するパーライトセメン タイト端部であり，Y型のフェライト粒界に囲まれた部分 のパーライトの粒状化は他の部分より粒状化が進行してい る。また，Y型のフェライト粒界に括いては他の部分より 遊離セメンタイトの成長が進行している.これらの観察結 果はパーライトセメンタイトが分解し， C 原子の一部はフ ェライト粒界に遊離セメンタイトとして再析出することを 意味している. 
Photo.2 は原組織が微細パーライトの場合の原組織と 400 サイクル後の組織である。原組織が微細パーライトの 場合の粒状化はパーライトコロニー内外でほぼ同時に起こ る. 艺して，粒状化は原組織が層状パーライト(Photo.1) の場合より急速である。

Photo. 3 は $\mathrm{Fe}-0.32 \% \mathrm{C}$ 鋼の場合の組織の変化を示し たものである、Fe- $0.32 \% \mathrm{C}$ 鋼の繰返加熱によるパーライ トの粒状化は市貶の S 35C の場合と比較して著しく急速で あり、フェライト粒界に遊離セメンタイトとして析出する 傾向がきわめて著しい，400サイクル後ではパーライトセ メンタイトの大部分が遊離セメンタイトとして粒界に析出 している.

Fig.2は原組織と繰返加熱によるパーライトコロニー量
ニー量が減少している.この減少率は原組織のパーライト が微細な浮ど大きい、コロニー量の減少はハーライトの粒 状化の程度汶対応するものであり，繰返加熱によるパーラ イトの粒状化はパーライトが微細なほど急速に進行するこ とを示している。な招.2のコロニー量はパーライト の粒状化が著しく進行した場合には粒状化の程度と対広し なくなる傾向がある。これはパーライトコロニー内部に特 ける粒状化を無視しているためである，現在，パーライト の粒状化の程度を定量的に示す方法はない。種々の方法炕 てポイントカウンティングを行ない,つぎの方法が組織と 最も対応することが明らかとならた。すなわら，検鏡倍率 400 倍の組織を 2000 倍まで引伸しを行ない，印画紙上に $100 \times 100 \mathrm{~mm}$ の測定視野 (15 視野以上) を選び，総計 400

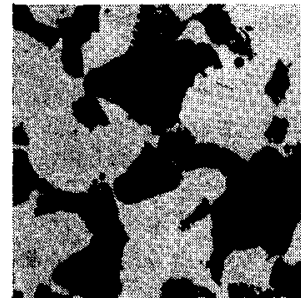

HT

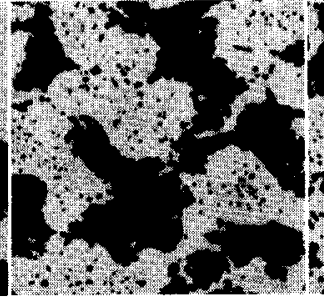

50 cycle

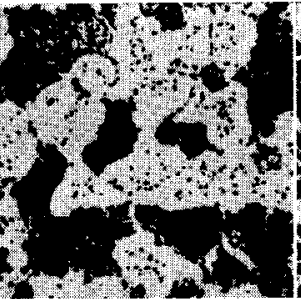

200 cycle

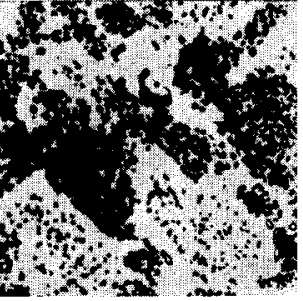

400 cycle

Photo.1 Microstructures, as annealed(HT) and after thermal cycling. $\mathrm{HT}: 0.39 \% \mathrm{C}$, ferrite + coarse lamellar pearlite $(\times 400)$

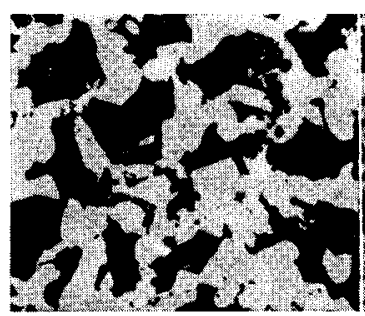

HT

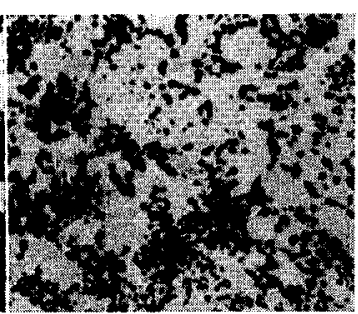

400 cycle

Photo.2 Microstructures, as normalized(HT) and after thermal cycling. HT : $0.39 \% \mathrm{C}$, ferrite + fine lamellar pearlite $(x 400)$

格子点(格子間卧離 $5 \mathrm{~mm}$ ) の直下に位置する組織を分類し て数觉る方法である。この報告では上述のポイントカウン ティングの方法を「簡便法」と称し，前報 ${ }^{(4)(5)}$ とて用いた 通常の方法（組織の量を2格子点中央の数として測定する 方法をを「全数法」と呼び，これらを区別することにする。

Fig.3 は「簡便法」にて測定したパーライトの粒状化率 と繰返数の関係である。ペーライトの粒状化率 $(S p h)$ はつ ぎの式で求め.

$$
S p h=(C+c f) /(P+C+c f) \times 100(\%)
$$

$P:$ 層状のパーライトセメンタイトの格子点数

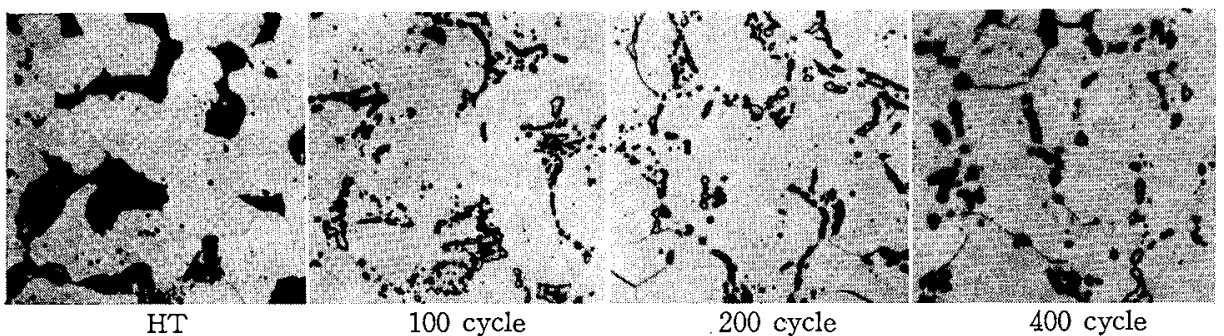

Photo.3 Microstructures, as annealed(HT) and after thermal cycling. $\mathrm{HT}$ : pure $\mathrm{Fe}-0.32 \% \mathrm{C}$, ferrite + coarse lamellar pearlite $(\times 400)$

の変化との関俰を前報 ${ }^{(3)}$ と同じ方法で測定した結果を示し たるのである、パーライトコロニーはパーライトセメンタ イトが密集した部分と定義しコロニー周辺部に認められ る修先的に成長した粒状セメンタイトはコロニー量に含め ないで測定した．Fig.2にて明らかなように原組織の如何 にかかわらず，いずれの場合も繰返数の增加に伴ないコロ

\section{$C:$ 粒状のセメンタイトの格子点数} $c f:$ 微粒セメンタイトの格子点数

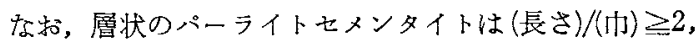
扣よび分解不可能な微紐なパーライトと定義した。 パーラ イトの粒状化の程度を上式で示すことには異論もある が,「全数法」より組織との対応性がよい。 
Fig.3によると繰返数の増加ととるに粒状化率が增加す る. 原組織が微細パーライトの場合の 400 サイクル後の粒 状化率は粗い層状パーライトの場合の約 2 倍 (92\%)であつ た. $\mathrm{Fe}-0.32 \% \mathrm{C}$ 鋼と S $35 \mathrm{C}$ とを粒状化率が $50 \%$ に到達す るために要する繰返数で比較すると， $\mathrm{Fe}-0.32 \% \mathrm{C}$ 鋼のパ ーライトの粒状化の速さは S $35 \mathrm{C}$ の 10 倍以上である。こ のよ5に「簡便法」によるとパーライトの料状化を定量 的に比較することが容易となる。パーライトが緻細なほど 粒状化が急速なのは，パーライトが微細な活どパーライト セメンタイトに分解しやすい不安定な部分が多いためと考 兄られる. Fe-0.32\%C鋼のパーライトの粒状化が著しく急 速なのは，市肘の S 35C より不純物元素，とくに Mnのご 上き炭化物を安定化する元素が少ないためと考克られる。

な特， $\mathrm{Fe}-0.32 \% \mathrm{C}$ 鋼には微粒せメンタイトが注之んど 認められないが，保持時間を短かく(30 sec 以下)すると微 粒セメンタイトが多数析出する.

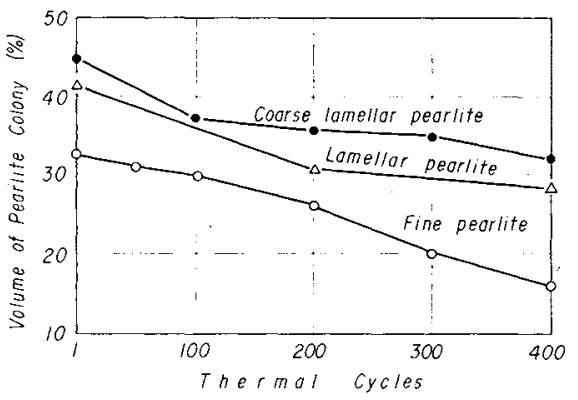

Fig.2 Effect of the original microstructure (HT) on the relation between the pearlite colony and the number of thermal cycles

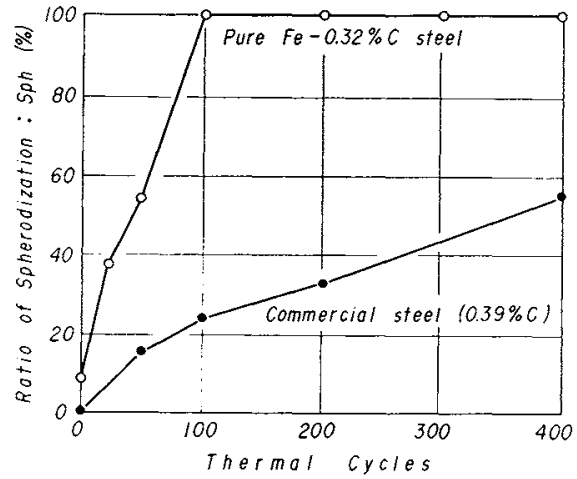

Fig.3 Relation between the ratio of spherodization of pearlite and the number of thermal cycles. The $S p h$ was measured by the modified point counting method

\section{2. 定常的加熱による垔共析炭素鋼の 影徽鏡組織の变化}

Photo.4は原組織が粗い層状パーライトの場合の保持時 間が $50 \mathrm{hr}$ 打よび $200 \mathrm{hr}$ 後の組織である，定常的加熱仗よ りパーライトは分解し，粒状化する．初析フェライトには 微粒セメンタイトは析出しない，定常的加熱によるパーラ イトの粒状化の特色は粒状化が緩慢であり，特定のセメン
タイトが優先成長することであるそとして，この優先成長 はフェライト粒界においてとくに著しい，定常的加熱の場 合原組織のパーライトが微細なほどハーーライトの粒状化 が急速である。

Fig.4は定常的加熱の場合の保持時間とパーライトコロ ニ一量括よび粒状化率の関係を示したものである，原組織 が微紐パーライトの場合は保持時間 $100 \mathrm{hr}$ 亿てパーライ

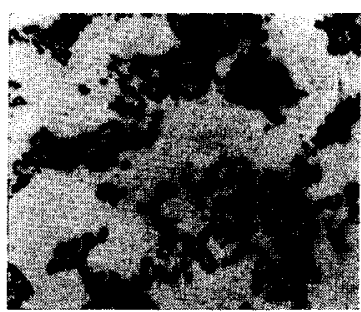

$50 \mathrm{hr}$

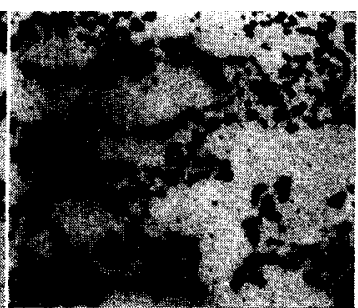

$200 \mathrm{hr}$
Photo. 4 Microstructures after steady heating. Original microstructure: same as HT of Photo.1. Steady heating : $690^{\circ} \mathrm{C} \times t \mathrm{hr}$, WC $(\times 400)$

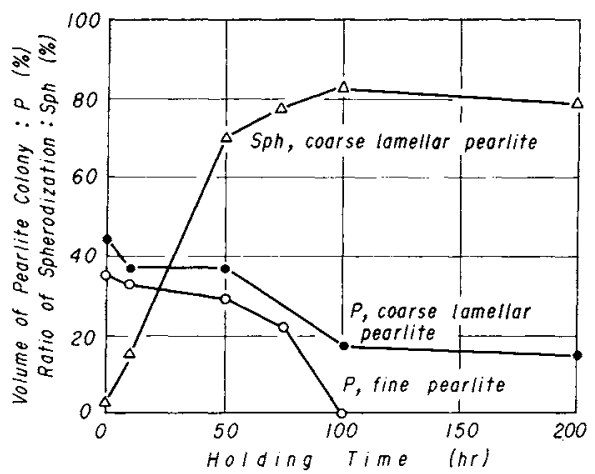

Fig. 4 Relation between the ratio of spherodization of pearlite and pearlite colony, and the holding time of steady heating

トコロニーが消失しているのに対し，原組織が粗い層状パ ーライトの場合は $200 \mathrm{hr}$ 後においてもコロニーが残存し ている。すなうち，微細パーライトのパーライトの粒状化 は粗い゚ーライトの場合の 2 倍以上急速である，原組織が 粗い層状パーライトの粒状化率は $100 \mathrm{hr}$ まで急激炕增加 するが $100 \mathrm{hr}$ 以上ではほとんど变化しない，これは定常的 加熱の昜合のパーライトの粒状化は一部のパーライトセメ ンタイトのとくに不安定な部分で起こり，残部のパーライ トセメンタイトはすでに粒状化を開始しているセメンタイ トの成長のためのC 原子供給源となるためと考古られる。

$\mathrm{Fe}-0.32 \% \mathrm{C}$ 鋼の定常的加熱後の組織（写真省略）は Photo. 3 と類似した組織であり，市販の S 35 C の場合より粒状化 が著しく急速であった。

\section{3. 加熱冷却繰返しと定常的加熱の比較}

Photo. 5 は綝返加熱扣よび定常的加熱によるパーライト の粒状化の相違を示す典型的な組織の一例であり，検鏡倍 率は 1000 倍である。繰返加熱の場合の粒状化は見掛け上 
は長いパーライトセメンタイトが寸断され, 短かい棒状の セメンタイトとなり, その後に粒状化するよ5に観察され る. Photo. 5 より繰返加熱の場合の粒状セメンタイトは非 常に微細であり,大きさが均一であることが明らかである. コロニー内の粒状セメンタイトの直径は原組織のパーラ イトセメンタイトの厚さ (巾)とほぼ同じである.コロニー 周辺に優先成長したセメンタイトが認められるが，これら は粒界に析出している遊離セメンタイトである。一方, 定 常的加熱の場合は著しく成長したセメンタイトが多く, 粒 界に拈ける優先成長が著しい.コロニ一内に打ける粒状セ メンタイトは棈円形であり，大きさが不均一である，そし て，原組織のパーライトセメンタイトの厚さより大きいも のが認められる.このよ5に繰返加熱の場合と定常的加熱 の場合とはパーライトの粒状化の状態が異なる. 要するに 繰返加熱の場合は均一な大きさの粒状セメンタイトになる のに対し, 定常的加熱の場合は不均一な大きさの粒状セメ ンタイトとなり, 粒界に拈ける遊離セメンタイトの成長が 著しい：このような相違は，繰返加熱によりパーライトセ メンタイトの分解する位置が定常的加熱の場合より多くな るためと考えられる。

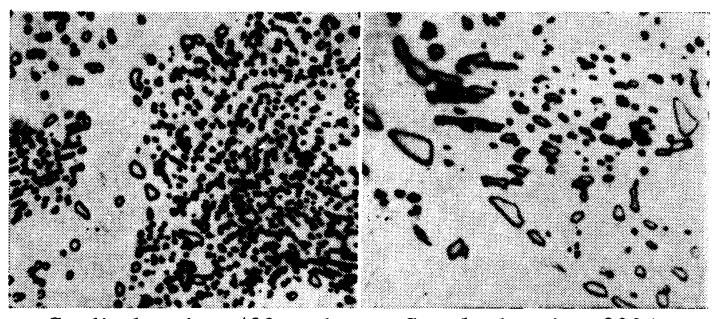

Cyclic heating 400 cycle Steady heating $200 \mathrm{hr}$

Photo.5 Typical spherodized pearlite of the cyclic heating and steady heating $(\times 1000)$

Fig.5は原組織が粗い層状パーライトの場合の繰返加熱 と定常的加熱による組織と硬度を比較した図である. 繰返

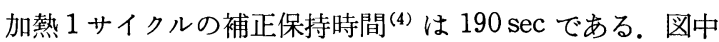
の C $p$ はパーライトコロニー内部の粒状セメンタイトの全 数を検鏡倍率 1000 倍(引伸倍率 5000 倍)にて測定した值で ある.

前述のごとく繰返加熱の場合と定常的加熱の場合ではパ 一ライトの粒状化過程が幾分異なり，粒状化率 $(S p h)$ によ り繰返加熱と定常的加熱とを比較することには多少問題が あるが，繰返加熱の場合のパーライトの粒状化の速さは定 常的加熱の場合の 2 倍以上であると考えてよい. $C p$ が最 大値となる時間により繰返加熱と定常的加熱とを比較する と, 繰返加熱の場合はパーライトの粒状化が 15 倍以上急 速に進行していることになる. 図は省略したが，パーライ トコロニー量 $(P)$ によつて比較すると, 繰返加熱の場合の 粒状化の速さは定常的加熱の 5 倍以上急速である. 硬度 (Hv) はいずれの場合も補正保持時間（繰返数，保持時間) の増加とともに減少し，補正保持時間が同じ場合，硬度は 同じかあるいは繰返加熱のほうがわずかに低い，硬度がほ
ぼ同じになるのは繰返加熱の場合，パーライトが粒状化し ても著しく分散することがないことに対応するものと考え られる。

上述のように $S p h, C p$ および $P$ を比較した結果, 繰返加 熱によるパーライトの粒状化の速さは定常的加熱の場合の 2〜15 倍であることが明らかとなつた.

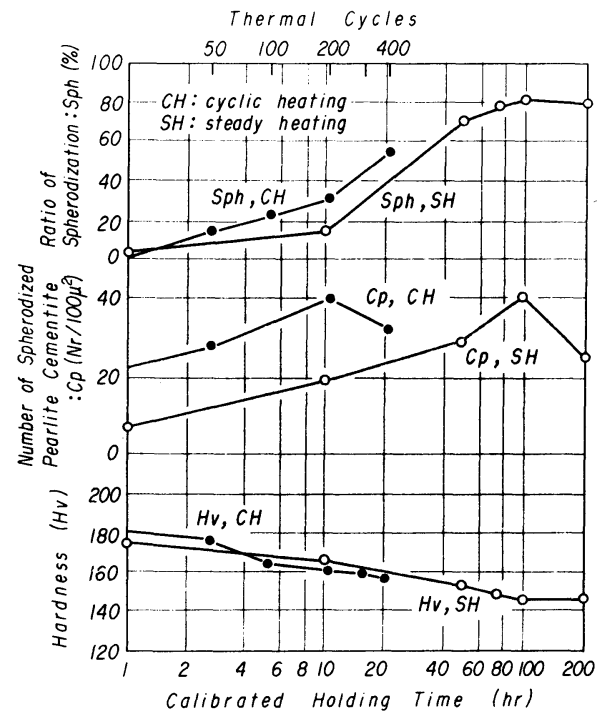

Fig.5 Relation between caribrated holding time and ratio of spherodization, number of spherodized pearlite cementite and hardness

前述のごとく，繰返加熱の場合パーライトセメンタイト があたかも機械的に寸断され，その位置で粒状化したよう にして進行している：そして，Cp も著しく大きい：この ことは繰返加熱の場合は扁平状のパーライトセメンタイト の多くの位置でセメンタイトの分解と粒状化が同時に進行 することを示するのである，セメンタイトの分解が起こる 不安定な位置はセメンタイトの凹部(曲率の大きい部分)(14) と考えられる. 繰返加熱の泠却過程に試験片全体の熱応力, パーライトコロニーとフェライト間の微視的熱応力拈よび セメンタイトとフェライト間の微視的熱応力などが，パー ライトセメンタイトの凹部付近に集中するため凹部が分解 しやすくなるものと考学られる。これらの熱応力が如何な る機構でセメンタイトを分解させるかは明らかでないが， 凹部付近に転位が発生する可能性が考えられるので将来検 討したい. $\mathrm{Fe}-0.32 \% \mathrm{C}$ 鋼 (Photo.3) の場合は繰返加熱の 場合であつても粒界に拈いて遊離セメンタイトが成長する 傾向が認められた. 市販の亜共析炭素鋼は繰返加熱による パーライトの粒状化がフェライト粒界付近に拈いて著し い.これらの実験事実はパーライトセメンタイトの分解に よつて生じた C 原子がフェライト粒界に拡散し, 遊離セメ ンタイトとして再析出することによりパーライトセメンタ イトの分解および粒状化が進行することを示すものと考兄

（14）佐藤，西沢：本誌，20(1956)，51. 
られる.

Photo.6は粒界のセメンタイト(パーライト)が微粒セメ ンタイトのC原子供給源であることを示す組織である. Photo. 6 は電解鉄打よび電解ニッケルを素材として溶製し た $2 \% \mathrm{Ni}$ 鋼 $(0.18 \% \mathrm{C}, 2.02 \% \mathrm{Ni})$ の炉冷材の原組織と繰 返加熱 $\left(600^{\circ} \mathrm{C} 4 \mathrm{~min} \mathrm{WC}\right)$ を 400 サイクル行なつた組織で ある.Photo.6にて明らかなように繰返加熱により粒界の セメンタイトが分解し，そのC原子がフェライト粒内に拡 散して微粒セメンタイトとして析出する. したがつて，パ ーライトセメンタイトが分解した場合，C原子はフェライ ト粒界を経由してフェライト粒内に拡散すると考岳なけれ ばならないすすなわち，微粒セメンタイトの析出るパーラ イトの粒状化を促進する重要な因子である。しかし, 繰返 数の増加に伴な弓微粒七メンタイトの数の増加には一定の 限度(熱サイクルの諸元により定まる)があり，その成長は 緩慢なので微粒セメンタイトがパーライトの粒状化を促進 するのは繰返加熱初期の過程と考㝋なければならない．

上述の上5に絽返加熱の場合は急速にパーライトの粒状 化が進行し，粒状化により微細でしかも均一な大きさの粒 状セメンタイトに変化する特色を有している，そして，パ ーライトの粒状化は初析フェライトの影響を受ける。すな わち, 前述した熱サイクルの冷却過程の熱応力のほかに, 微粒セメンタイトの析出もパーライトの粒状化を促進する 因子と考学なければならない。このように繰返加熱による 組織の变化には二,三の特色を有し，定常的加熱の場合と は本質的に異なつた因子が存在するものと考光なければな らない，すなわち, 繰返加熱中の空孔および転位などの挙 動についても検討し, 繰返加熱による組織の变化との関係 を明らかにする必要があると考兄られる.

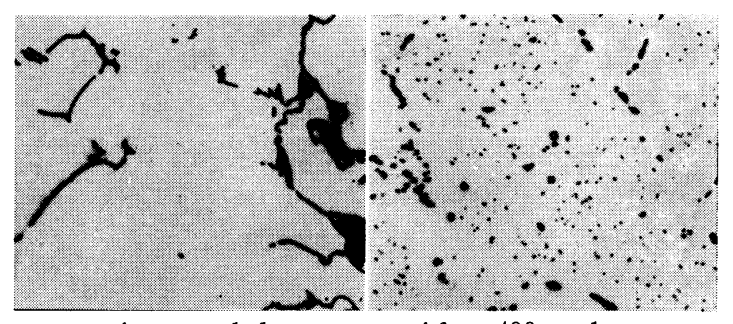

As annealed

After 400 cycles

Photo.6 Microstructure, as annealed and after thermal cycling. Specimen : $0.18 \% \mathrm{C}$, $2.02 \% \mathrm{Ni}$. Thermal cycle : $600^{\circ} \mathrm{C} \times$ $4 \mathrm{~min}$ WC $(\times 400)$

\section{IV. 総括}

覀共析炭素鋼を共析変態点以下で加熱冷却繰返しを行な つた場合の顕微鏡組織の変化, とくにパーライトの粒状化 現象をポイントカウンティング法により詳細に調べて報告 した.

熱処理により加熱冷却絽返し前の組織(原組織)を粗い層
状パーライト，層状パーライトおよび微細パーライトにし て「塩浴浸漬加熱-水冷方式」により, 共析変態点以下の繰 返加熱を行ない, 原組織とパーライトの粒状化過程の関係 を調べた，さらに，繰返加熱による組織の変化の特色を明 らかにするため, 繰返加熱と同じ加熱括よび冷却条件の定 常的加熱(恒温連続加熱)を行ない，その組織の変化を調べ た。 パーライトの粒状化過程の組織解析は数種の方法にて 行なつた。 パーライトの粒状化の程度を測定するポイント カウンティング法として新たに「簡便法」を用いた。 この 方法は従来の方法を多少修正したものであり，パーライト の粒状化の程度は粒状化率 (Sph\%) 飞て表わした。

繰返加熱により層状パーライトは粒状化し，硬度は減少 する，パーライトの粒状化は原組織のパーライトが微細な ほど急速に進行する。原組織が微細パーライトの場合のパ ーライトの粒状化の速さは原組織が粗い層状パーライトの 場合の 2 倍以上であつた．不純物元素を含まない亜共析炭 素鋼のパーライトの粒状化率は市販の亜共析炭素鋼の 10 倍以上急速に進行する.

定常的加熱の場合の原組織とパーライトの粒状化との関 係は繰返加熱の場合と同じであつた。

繰返加熱の場合のパーライトの粒状化の速さは定常的加 熱の場合の 2 倍以上であつた。繰返加熱によるパーライト の粒状化は粒状化したパーライトセメンタイトが微細で, しかも大きさが均一であり，粒状化によりパーライトコロ 二一の形が著しく崩れないことに特色を有している. 一 方, 定常的加熱の場合はフェライト粒界に拈ける遊離セメ ンタイトの成長が著しく，パーライトコロニー中に执いて あ特定のセメンタイトが優先成長する傾向がある.

繰返加熱によるパーライトの粒状化が定常的加熱の場合 より急速である原因を検討した結果, 繰返加熱によりパー ライトセメンタイトの多くの位置で分解しやすくなること 扣よび初析フェライト中に微粒セメンタイトが析出するた めであることが明らかとなつたすすなわち，パーライトセ メンタイトのC原子がフェライト粒界を経由してフェライ 卜粒内に拡散し, 微粒セメンタイトのC供給源となるた め, 繰返加熱初期にパーライトセメンタイトの粒状化を促 進するすのと考兄られる.

繰返加熱淿よる亚共析炭素鋼の組織の変化は初析フェラ イトに微粒セメンタイトが析出すること,およびパーライ トの粒状化が著しく急速であり, 粒状化により微細でしか も均一な粒状セメンタイトになることに定常的加熱の場合 にはみられない特色がある。これらの特色と熱疲労現象と の関係は現状では明らかでないが, 熱疲労現象の金属組織 学的解明を目的として行なつた一連の実験結果について引 続き報告する予定である.

終りに本研究に際し御助言をいただいた北海道大学工学 部 萩原教授扣よび室蘭工業大学 金森教授に謝意を表す る. 